\title{
PIK3R2/USP8 Fusion Protein
}

National Cancer Institute

\section{Source}

National Cancer Institute. PIK3R2/USP8 Fusion Protein. NCI Thesaurus. Code C99588.

A fusion protein encoded by the PIK3R2/UPS8 fusion gene. This protein is comprised of most of the phosphatidylinositol 3-kinase regulatory subunit alpha protein, excluding the second $\mathrm{SH} 2$ domain, fused to the $\mathrm{C}$-terminus of the ubiquitin carboxyl-terminal hydrolase 8 protein. 